\title{
Peningkatan Kualitas Produk Roti Manis pada PT Indoroti Prima Cemerlang Jember Berdasarkan Metode Statistical Process Control (SPC) dan Failure Mode and Effect Analysis (FMEA)
}

\author{
(The Quality Improvement of Sweet Bread Product of PT Indoroti Prima Cemerlang \\ Jember Based on Statistical Process Control (SPC) Method and Failure Mode and \\ Effect Analysis (FMEA) Method)
}

Elisa Mardya Ratri, Eka Bambang $\mathrm{G}^{1}$, Marmono Singgih

Jurusan Manajemen, Fakultas Ekonomi dan Bisnis, Universitas Jember (UNEJ)

Jln. Kalimantan 37, Jember 68121

E-mail: dyaraelisa91@gmail.com

\begin{abstract}
Abstrak
Penelitian ini bertujuan untuk melakukan pengendalian kualitas produk roti manis pada PT Indoroti Prima Cemerlang Jember dengan cara menganalisis keseluruhan jumlah roti yang diproduksi dan jumlah roti yang mengalami kerusakan pada jangka waktu tertentu dengan menggunakan metode Statistical Process Control (SPC) dan Failure Modes and Effect Analysis (FMEA). Pemilihan produk roti manis untuk diteliti didasarkan pada bukti data produksi roti selama bulan Januari 2017 yang menunjukkan bahwa tingkat kerusakan roti paling banyak ditemukan pada varian roti manis sehingga seharusnya perlu mendapatkan perhatian lebih dari perusahaan untuk mendapatkan prioritas perbaikan. Berdasarkan hasil analisis $p$ chart, kerusakan roti manis manis berada dalam batas kendali. Hal ini ditunjukkan dengan adanya keseluruhan titik berada di dalam batas garis UCL dan LCL. Adapun garis UCL adalah sebesar 0,0930, LCL sebesar 0,0238, dan p (garis tengah) sebesar 0,0085 . Jenis kerusakan yang terjadi pada produk roti manis antara lain penyok, kotor, isi keluar (bocor), kempes, dan terpotong. Adapun penyebab kerusakan dapat disebabkan oleh tiga faktor yaitu manusia, mesin, dan metode. Berdasarkan metode FMEA (Failure Mode and Effect Analysis) diketahui bahwa prioritas perbaikan untuk proses produksi dan pengepakan berbeda. Perbaikan pada proses produksi diprioritaskan pada faktor manusia, sedangkan perbaikan pada proses pengepakan diprioritaskan pada faktor mesin.
\end{abstract}

Kata Kunci: Failure Mode and Effect Analysis (FMEA), Pengendalian Kualitas, Statistical Process Control (SPC)

\begin{abstract}
This study aims to control the quality of sweet bread products at PT Indoroti Prima Cemerlang Jember by analyzing the total amount of bread produced and the amount of bread that is damaged over a period of time using Statistical Process Control (SPC) and Failure Modes and Effect Analysis ( FMEA).. Selection of sweet bread that will be studied is based on the proven data of bread production on Januari 2017 which show that the most damaged product were found in sweet bread variant, so it needs to get more attention from the company in priority improvement. Based on the $\mathrm{p}$ chart, the damage of sweet breads is within control limits. It is indicated by the whole point that are within UCL dan LCL. The UCL line is 0,0930, LCL line is 0,0238 , and $\mathrm{p}$ (midline) is 0,0085 . The types of damage which happened to the sweet breads are dents, filthy, leak, defa ted, and truncated. The damaged can be caused by three factors such as man, machine, and method. Based on FMEA (Failure Mode and Effect Analysis) Method, it shows that the priority improvement for production and packing process are different. Improvement in production process prioritized on man factor, while improvement in packing process prioritized on machine factor.
\end{abstract}

Keywords: Failure Mode and Effect Analysis (FMEA), Quality Control, Statistical Process Control (SPC)

\section{Pendahuluan}

Usaha industri manufaktur di Era Globalisasi semakin berkembang. Perkembangan industri manufaktur menjadikan persaingan semakin ketat sehingga perusahaan dituntut untuk terus mengembangkan usahanya, tidak hanya dalam lingkup skala regional dan nasional tetapi juga skala Internasional. Perusahaan Indonesia harus mampu membuktikan bahwa produk yang dihasilkan Indonesia tidak kalah baiknya dengan produk-produk luar negeri. Salah satu cara yang dapat dilakukan untuk menghadapi keadaan tersebut adalah berusaha dengan sungguh-sungguh untuk menghasilkan produk dalam negeri yang berkualitas. Untuk dapat menghasilkan produk yang berkualitas tidak lah mudah, setiap perusahaan harus memiliki strategi

1 Corresponding Author produksi yang baik, mulai dari awal proses pembuatan hingga produk tersebut siap untuk dipasarkan. Orientasi yang perlu diperhatikan perusahaan dalam menghasilkan suatu produk adalah mengenai pemenuhan kebutuhan dan kepuasan konsumen. Artinya produk yang dihasilkan tidak hanya semata-mata untuk mencapai tujuan perusahaan (profit oriented), tetapi juga perlu memiliki spesifikasi produk yang harus memerhatikan kebutuhan dari konsumennya.

Barang dapat dikatakan berkualitas apabila sesuai dengan standar kualitas produk yang telah ditetapkan oleh perusahaan. Setiap proses produksi memiliki peluang menghasilkan produk yang tidak sesuai dengan standar kualitas. Produk yang tidak sesuai dengan standar tersebut 
dapat dianggap sebagai produk rusak/cacat (defect) yang tidak dapat langsung disalurkan ke pasar tetapi harus melalui proses penyortiran atau pun perbaikan terlebih dahulu. Produk cacat merupakan barang atau jasa yang dibuat dalam proses produksi namun memiliki kekurangan yang menyebabkan kualitasnya kurang baik atau kurang sempurna. Menurut Hansen dan Mowen (2001), produk cacat adalah produk yang tidak memiliki spesifikasi. Terdapat beberapa penyebab yang menimbulkan produk yang dihasilkan tidak sesuai dengan standar, baik itu faktor sumber daya manusia, mesin, metode, bahan baku, dan lingkungan.

Kegiatan pengendalian dan perbaikan kualitas merupakan salah satu upaya yang dapat dilakukan oleh perusahaan untuk memperbaiki kerusakan/kecacatan produk dan menekan jumlah produk rusak/cacat yang terjadi selama proses produksi sampai pada tingkat kerusakan nol (zero defect), menjaga agar produk yang dihasilkan memenuhi standar yang telah ditetapkan perusahaan, dan mencegah agar produk rusak/cacat tidak lolos ke tangan konsumen. Kegiatan pengendalian dan perbaikan kualitas tidak hanya dilakukan sekali atau dua kali ketika terjadi permasalahan saja, tetapi harus dilakukan secara berkelanjutan oleh perusahaan guna menjaga dan mempertahankan kualitas produk agar selalu baik serta sebagai bahan evaluasi dan pengambil keputusan serta tindakan yang perlu dilakukan terkait dengan pengendalian kualitas produk.

PT Indoroti Prima Cemerlang Jember adalah salah satu industri yang bergerak dalam bidang produksi roti dengan merek dagang Mr. Bread. Alamat perusahaan bertempat di Jalan Piere Tendean No. 99 A Sumbersari, Jember. PT Indoroti Prima Cemerlang Jember memproduksi dua jenis roti yaitu roti tawar dan roti manis yang mana masingmasing jenis roti memiliki beberapa varian dengan jumlah keseluruhan ada 23 varian roti yang meliputi 7 varian roti tawar dan 16 varian roti manis. Untuk dapat mencapai produk yang berkualitas baik maka PT Indoroti Prima Cemerlang Jember harus memperhatikan beberapa hal, baik dari segi kualitas bahan baku, peralatan, metode, Sumber Daya Manusia, maupun lingkungan. PT Indoroti Prima Cemerlang Jember dalam mempertahankan kualitas roti yang diproduksi, pasti memiliki standar kualitas produk yang harus dicapai, walaupun pada kenyataannya masih ditemukan roti yang mengalami kerusakan. Untuk roti yang mengalami kerusakan kemudian disortir dan dipisah dari roti yang berkriteria baik dan akan dijual kembali ke pihak lain dengan harga yang lebih rendah, hal ini tentunya dapat berdampak negatif bagi perusahaan karena dapat menimbulkan kerugian apalagi produk yang rusak terjadi secara terus menerus dan dalam jumlah yang tidak sedikit.

Berdasarkan uraian yang telah dijelaskan di atas menunjukkan bahwa pengendalian kualitas produk pada sebuah perusahaan sangat penting untuk dilakukan. Hal ini guna mengurangi tingkat kerusakan/kecacatan produk sehingga dapat menghasilkan produk akhir yang berkualitas. Untuk dapat melakukannya, pihak perusahaan harus mengetahui terlebih dahulu faktor-faktor penyebab terjadinya kerusakan/kecacatan produk. Dalam penelitian ini, penulis akan melakukan pengendalian kualitas produk roti manis pada PT Indoroti Prima Cemerlang Jember dengan cara menganalisis keseluruhan jumlah roti manis yang diproduksi dan jumlah roti manis yang mengalami kerusakan pada jangka waktu tertentu dengan menggunakan metode SPC (Statistical Process Control) dan FMEA (Failure Modes and Effect Analysis). Pemilihan pengendalian kualitas pada roti manis didasarkan pada data jumlah roti yang rusak selama bulan Januari 2017 yang menunjukkan bahwa tingkat kerusakan produk sebagian besar terjadi pada varian roti manis sehingga seharusnya perlu mendapatkan perhatian lebih dari perusahaan untuk mendapatkan prioritas perbaikan. Dengan menggunakan kedua metode tersebut diharapkan mampu untuk mengurangi terjadinya penyimpangan dan produk rusak yang ada di perusahaan sehingga dapat dijadikan sebagai bahan evaluasi dan pertimbangan perbaikan dalam pengendalian kualitas secara berkelanjutan guna meningkatkan produktivitas dan kualitas produk roti ke depannya menjadi lebih baik.

Berdasarkan uraian di atas, maka rumusan masalah dalam penelitian ini antara lain sebagai berikut: 1) apakah tingkat kerusakan roti manis pada PT Indoroti Prima Cemerlang Jember masih berada dalam batas kendali atau tidak secara statistik?; 2) apa saja faktor penyebab kerusakan roti manis pada PT Indoroti Prima Cemerlang Jember?; dan bagaimana solusi perbaikan yang dapat dilakukan guna mengurangi kerusakan roti manis pada PT Indoroti Prima Cemerlang Jember?

Adapun tujuan dari penelitian ini meliputi 1) untuk menganalisis tingkat kerusakan roti manis pada PT Indoroti Prima Cemerlang Jember masih berada dalam batas kendali atau tidak secara statistik; 2) untuk mengidentifikasi faktor penyebab terjadinya kerusakan roti manis pada PT Indoroti Prima Cemelang Jember; dan 3) untuk menganalisis solusi perbaikan yang dapat dilakukan guna mengurangi kerusakan roti manis pada PT Indoroti Prima Cemerlang Jember.

\section{Metode}

Berdasarkan latar belakang masalah dan rumusan masalah yang ada, penelitian ini menggunakan jenis penelitian deskriptif kuantitatif. Faisal (dalam Sakti, 2014:16) menyatakan bahwa jenis penelitian deskriptif kuantitatif adalah penelitian yang berupa angka-angka yang selanjutnya dari hasil analisis tersebut akan diperoleh gambaran dari suatu kondisi yang ada sebagai dasar pemecahan persoalan yang telah dirumuskan.

Pemilihan jenis penelitian ini didasarkan pada judul penelitian yang mengarah pada studi kasus yang mana data utama yang digunakan untuk menganalisis permasalahan adalah menggunakan angka-angka. Dalam penelitian ini, peneliti akan menganalisis standar kualitas produk roti manis PT Indoroti Prima Cemerlang Jember berdasarkan jumlah rusak yang terjadi, jenis-jenis kerusakan, dan faktorfaktor penyebab terjadinya produk rusak dengan menggunakan metode Statistical Process Control (SPC) dan Failure Modes and Effect Analysis (FMEA) untuk menjadi bahan pertimbangan bagi perusahaan guna mengetahui dan menentukan prioritas perbaikan yang akan dilakukan untuk mengurangi terjadinya kerusakan roti manis pada kegiatan produksi selanjutnya. 
Analisis data yang digunakan dalam penelitian ini menggunakan dua metode yaitu Metode Statistical Process Control (SPC) dan Failure Mode and Effect Analysis (FMEA). Adapun langkah-langkah yang dilakukan adalah sebagai berikut:

a. Analisis data dengan menggunakan metode Statistical Process Control (SPC)

1) Mengumpulkan data menggunakan check sheet

Data yang diperoleh dari perusahaan terutama yang berupa data produksi dan data kerusakan produk kemudian disajikan dalam bentuk tabel secara rapi dan terstruktur dengan menggunakan check sheet. Hal ini dilakukan agar mudah dalam memahami data tersebut sehingga bisa dilakukan analisis lebih lanjut.

2) Membuat histogram

Langkah selanjutnya setelah membuat check sheet adalah membuat histogram. Histogram adalah alat penyajian data secara visual berbentuk balok yang memperlihatkan distribusi nilai yang diperoleh dalam bentuk angka. Tujuan dari histogram ini adalah agar penyajian data yang diperoleh menjadi lebih menarik dan mudah untuk dibaca.

\section{3) Membuat Peta Kendali P (P-chart)}

Dalam menganalisis penelitian ini, digunakan peta kendali $\mathrm{p}$ ( $p$-chart) sebagai alat untuk mengendalikan secara statistik. Penggunaan peta kendali $\mathrm{p}$ ini dikarenakan pengendalian kualitas yang dilakukan bersifat atribut dan data yang diperoleh yang dijadikan sampel pengamatan jumlahnya tidak tetap serta produk yang diteliti tergolong sebagai produk yang apabila mengalami kerusakan tidak dapat dipebaiki kembali sehingga harus ditolak (reject).

Adapun langkah-langkah membuat peta kendali $\mathrm{p}$ adalah sebagai berikut (Heizer dan Render, 2006):

(a) Menghitung presentase kerusakan.

$$
p=\frac{n p}{n}
$$

\section{Keterangan:}

$\mathrm{np}$ : Jumlah gagal dalam sub grup

$\mathrm{n}$ : Jumlah yang diperiksa dalam sub grup

Sub grup : Hari ke-

(b) Menghitung garis pusat/ center line (CL).

Garis pusat merupakan rata-rata kerusakan produk

$$
C L=\bar{p}=\frac{\sum n p}{\sum n}
$$

Keterangan:

$\Sigma \mathrm{np}$ : Jumlah total yang rusak

$\Sigma \mathrm{n}:$ Jumlah total yang diperiksa

(c) Menghitung batas kendali atas/ Upper Control Limit (UCL).

$$
U C L=\bar{P}+3 \sqrt{\frac{\bar{P}(1-\bar{P})}{n}}
$$

Keterangan:

p : Rata-rata kerusakan produk

n : Total produksi

(d) Menghitung batas kendali bawah/Lower Control Limit (LCL)

$$
U C L=\bar{P}-3 \sqrt{\frac{\overline{\bar{P}(1-\bar{P})}}{n}}
$$

Keterangan:

p : Rata-rata kerusakan produk

$\mathrm{n}$ : Total produksi

4) Membuat diagram pareto

Dari data informasi mengenai jenis kerusakan produk yang terjadi kemudian dibuat diagram pareto untuk mengidentifikasi, mengurutkan kerusakan produk. Dengan diagram ini, maka dapat diketahui jenis kerusakan yang paling dominan atau terbesar.

5) Mencari faktor penyebab yang dominan dengan diagram sebab akibat

Setelah diketahui masalah utama yang paling dominan, maka dilakukan analisa faktor penyebab kerusakan produk dengan menggunakan fishbone diagram, sehingga dapat menganalisis faktor-faktor apa saja yang menjadi penyebab kerusakan produk.

b. Menganalisis penyebab kegagalan dan membuat rekomendasi/usulan perbaikan kualitas dengan metode Failure Modes and Effect Analysis (FMEA)

Menurut Kosasih et al. (2015:2), beberapa langkah dalam melakukan proses FMEA adalah sebagai berikut:

1) Menentukan label pada masing-masing proses atau sistem

2) Membuat penjelasan mengenai fungsi proses

3) Mengidentifikasi jenis cacat yang terjadi

4) Mengidentifikasi akibat dari cacat yang terjadi

5) Menentukan nilai severity

Nilai tingkat keparahan terdiri dari rating 1-10, semakin parah akibat yang ditimbulkan maka semakin tinggi nilai rating yang diberikan

6) Mengidentifikasi penyebab cacat

7) Menentukan nilai occurance

Nilai tingkat kemungkinan diberikan untuk setiap penyebab cacat dan juga memiliki nilai rating dari 1-10. Semakin sering terjadi cacat maka semakin tinggi nilai rating yang diberikan.

8) Mengidentifikasi control yang dilakukan

9) Menetukan detection 
Nilai detection terdiri dari rating 1-10. Semakin sulit penyebab cacat dideteksi, maka semakin tinggi nilai rating yang diberikan.

10) Menghitung Risk Priority Number (RPN) yang dinyatakan dengan persamaan:

$\mathrm{RPN}=$ severity $x$ occurance $x$ detection

\section{Hasil Penelitian}

\section{Analisis Data Dengan Menggunakan Statistical Process} Control

Mengumpulkan Data Menggunakan Check Sheet (Tanggal 18 Maret s/d 16 April 2017)

Langkah pertama yang akan dilakukan untuk melakukan pengendalian kualitas secara statistik adalah membuat check sheet. Check sheet berguna untuk mempermudah proses pengumpulan data dan mengetahui area permasalahan berdasarkan frekuensi dari jenis atau penyebab serta mengambil keputusan untuk melakukan perbaikan atau tidak. Adapun data yang masuk dalam tabel check sheet adalah sebagai berikut:

\begin{tabular}{|c|c|c|c|c|c|c|}
\hline \multirow[b]{2}{*}{ No Tgl } & \multirow[b]{2}{*}{$\begin{array}{l}\text { Jumlah } \\
\text { Sampel }\end{array}$} & \multicolumn{4}{|c|}{ Jenis Kerusakan Produk } & \multirow[b]{2}{*}{$\begin{array}{c}\text { Jumlah } \\
\text { Sampel } \\
\text { Rusak }\end{array}$} \\
\hline & & $\begin{array}{l}\text { Pe- } \\
\text { nyok }\end{array}$ & $\begin{array}{l}\text { Ko- } \\
\text { Kem- } \\
\text { tor pes }\end{array}$ & $\begin{array}{c}\text { Isi } \\
\text { Keluar } \\
\text { (Bocor) }\end{array}$ & $\begin{array}{l}\text { Terpo- } \\
\text { tong }\end{array}$ & \\
\hline
\end{tabular}

\begin{tabular}{|c|c|c|c|c|c|c|c|c|}
\hline 1 & 18 & 900 & 2 & 2 & 4 & 2 & 14 & 24 \\
\hline 2 & 19 & 900 & 2 & 1 & 4 & 1 & 11 & 19 \\
\hline 3 & 20 & 900 & 3 & 2 & 6 & 1 & 14 & 26 \\
\hline 4 & 21 & 900 & 4 & 2 & 7 & 1 & 10 & 24 \\
\hline 5 & 22 & 900 & 2 & 2 & 5 & 3 & 15 & 27 \\
\hline 6 & 23 & 900 & 1 & - & 7 & - & 16 & 24 \\
\hline 7 & 24 & 900 & 2 & 1 & 5 & 1 & 15 & 24 \\
\hline 8 & 25 & 900 & 3 & - & 4 & 1 & 10 & 18 \\
\hline 9 & 26 & 900 & 2 & - & 5 & 1 & 11 & 19 \\
\hline 10 & 27 & 900 & 2 & 1 & 4 & 1 & 10 & 18 \\
\hline 11 & 28 & 900 & 4 & 1 & 5 & 2 & 12 & 24 \\
\hline 12 & 29 & 900 & 2 & 1 & 3 & 1 & 8 & 15 \\
\hline 13 & 30 & 900 & 2 & 1 & 4 & 2 & 11 & 20 \\
\hline 14 & 31 & 900 & 4 & 2 & 6 & 1 & 13 & 26 \\
\hline 15 & 1 & 900 & 1 & 1 & 2 & 2 & 12 & 18 \\
\hline 16 & 2 & 900 & 1 & 1 & 1 & 3 & 8 & 14 \\
\hline 17 & 3 & 900 & 4 & 2 & 5 & 1 & 10 & 22 \\
\hline
\end{tabular}

\begin{tabular}{ccccccccc}
18 & 4 & 900 & 1 & 1 & 3 & - & 8 & 13 \\
19 & 5 & 900 & 5 & 2 & 6 & 1 & 14 & 28 \\
\hline 20 & 6 & 900 & 4 & 2 & 7 & 2 & 11 & 25 \\
21 & 7 & 900 & 3 & 2 & 4 & 1 & 10 & 20 \\
22 & 8 & 900 & 5 & 2 & 6 & 1 & 12 & 26 \\
23 & 9 & 900 & 4 & 1 & 5 & - & 14 & 24 \\
24 & 10 & 900 & 4 & 1 & 5 & 1 & 9 & 20 \\
25 & 11 & 900 & 4 & 1 & 4 & - & 9 & 18 \\
26 & 12 & 900 & 3 & 2 & 6 & 1 & 10 & 22 \\
27 & 13 & 900 & 3 & 1 & 4 & 2 & 9 & 19 \\
28 & 14 & 900 & 3 & 1 & 6 & 1 & 9 & 20 \\
29 & 15 & 900 & 5 & 2 & 5 & 1 & 11 & 24 \\
30 & 16 & 900 & 4 & 2 & 5 & 1 & 9 & 21 \\
\hline Total & $\mathbf{2 7 0 0 0}$ & $\mathbf{8 9}$ & $\mathbf{4 0}$ & $\mathbf{1 4 3}$ & $\mathbf{3 6}$ & $\mathbf{3 3 4}$ & $\mathbf{6 4 2}$ \\
\hline
\end{tabular}

Sumber: Data primer diolah, 2017

Berdasarkan hasil check sheet diketahui bahwa jumlah produksi roti manis yang dijadikan sampel penelitian mulai tanggal 18 Maret s/d 16 April 2017 sebanyak 27.000 pcs dengan jumlah roti manis yang mengalami kerusakan sebanyak 642 pcs dengan rincian jumlah roti yang rusak karena penyok sebanyak 89 pcs, kotor sebanyak 40 pcs, kempes sebanyak 143 pcs, isi keluar (bocor) sebanyak 36 pcs, dan terpotong sebanyak 334 pcs.

\section{Membuat Histogram}

Setelah data jumlah produksi dan produk rusak dimasukkan ke dalam tabel check sheet, maka langkah selanjutnya adalah membuat histogram. Histogram berguna untuk melihat lebih jelas kerusakan produk yang terjadi sesuai frekuensi kerusakan. Data produk rusak tersebut disajikan dalam bentuk grafik betang yang terbagi berdasarkan jenis kerusakan masing-masing.

Histogram yang menunjukkan data produksi roti manis yang mengalami kerusakan pada tanggal 18 Maret s/d 16 April 2017 adalah sebagai berikut:

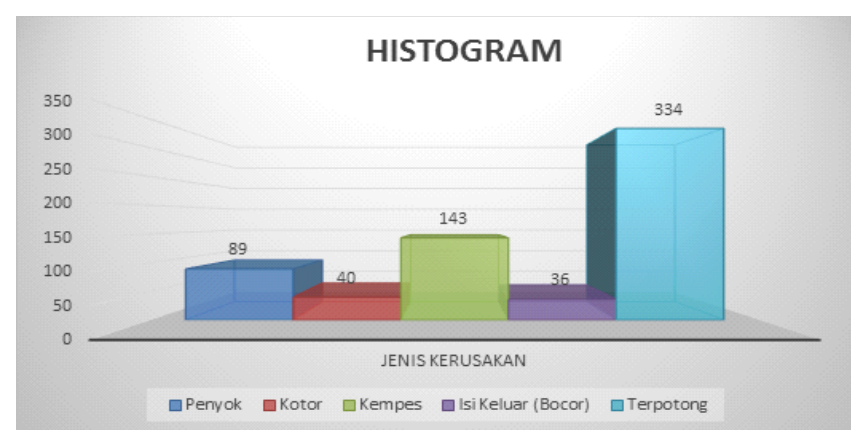

Sumber: Data primer diolah, 2017

Membuat Peta Kendali P (P-Chart) 
Setelah histogram dibuat, maka langkah selanjutnya adalah membuat peta kendali. Peta kendali merupakan grafik kendali yang berguna untuk mengetahui sejau mana kerusakan produk yang terjadi masih dalam batas kendali statistik atau tidak. Adapun tampilan dari peta kendali $\mathrm{p}(p$ chart) setelah melalui proses perhitungan persentase kerusakan, garis pusat/central line (CL), batas kendali atas/ upper control limit (UCL) dan batas kendali bawah/ lower control limit (LCL) adalah sebagai berikut:

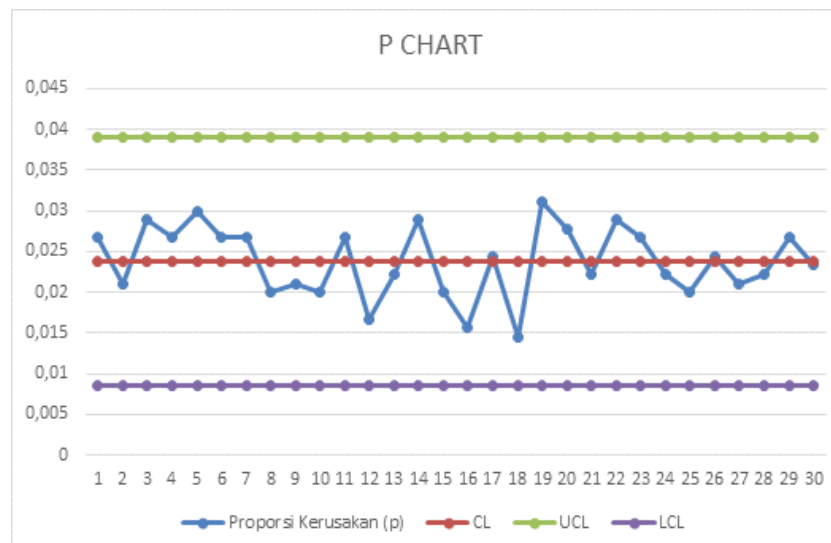

Sumber: Data primer diolah, 2017

Berdasarkan gambar peta kendali $\mathrm{p}$ ( $p$ chart) di atas dapat diketahui bahwa kerusakan roti manis masih berada dalam batas kendali, hal ini dapat ditunjukkan dengan seluruh titik masih berada di dalam batas garis Upper Control Limit (UCL) dan Lower Control Limit (LCL) sehingga bisa dikatakan bahwa proses terkendali. Meskipun demikian, pihak perusahaan tetap memerlukan pengendalian kualitas secara berkelanjutan sebagai up mengurangi terjadinya kerusakan produk seperti yang selama ini selalu terjadi.

\section{Membuat Diagram Pareto}

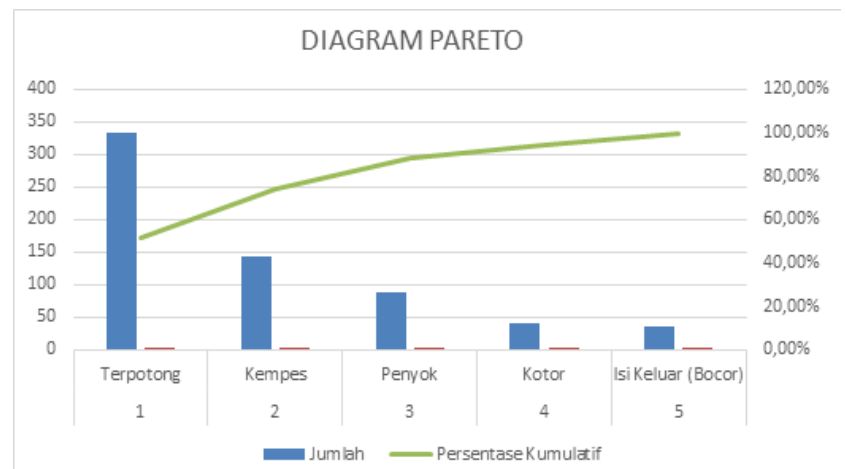

Diagram pareto adalah diagram yang digunakan untuk mengidentifikasi, mengurutkan jumlah kerusakan produk muali dari yang tertinggi (dominan) hingga terendah selama periode penelitian yaitu tanggal 18 Maret s/d 16 April 2017. Adapun tampilan dari diagram pareto dapat dilihat pada gambar berikut:Sumber: Data primer diolah, 2017

Berdasarkan diagram pareto dapat diketahui bahwa jenis kerusakan paling tinggi (dominan) terjadi pada jenis kerusakan terpotong dengan persentase $52,02 \%$, kemudian diikuti jenis kerusakan kempes dengan persentase 22,27\%, penyok dengan persentase $13,86 \%$, kotor dengan persentase $6,23 \%$, dan yang terendah adalah isi keluar (bocor) dengan persentase 5,61\%. Dengan demikian, perbaikan akan lebih baik difokuskan pada jenis kerusakan yang tertinggi (dominan) yaitu terpotong, kemudian diikuti dengan perbaikan pada jenis kerusakan berikutnya sesuai urutan.

\section{Mencari faktor penyebab kerusakan dengan menggunakan diagram sebab akibat (fishbone diagram)}

Diagram sebab akibat (fishbone diagram) adalah gambar yang terdiri dari garis dan simbol yang menunjukkan hubungan sebab akibat. Dalam diagram ini akan diketahui faktor-faktor yang mempengaruhi dan memperlihatkan hubungan permasalahan yang dihadapi dengan kemungkinan penyebabnya. Adapun faktor-faktor yang mempengaruhi dan menjadi penyebab kerusakan produk pada PT Indoroti Prima Cemerlang Jember dapat digolongkan sebagai berikut:

1) Man (manusia) yaitu para pekerja yang melakukan pekerjaan dan terlibat langsung dalam proses produksi.

2) Machine (mesin) yaitu mesin-mesin dan berbagai peralatan yang digunakan selama proses produksi.

3) Method (metode) yaitu instruksi atau perintah kerja yang harus dipahami, dipatuhi, dan dilaksakan dalam proses produksi.

Berdasarkan analisis penulis diperoleh Cause and Effect Diagram dengan rincian sebagai berikut:

\begin{tabular}{lll}
\hline $\begin{array}{c}\text { Jenis } \\
\text { Kerusakan }\end{array}$ & $\begin{array}{c}\text { Faktor } \\
\text { Penyebab }\end{array}$ & \multicolumn{1}{c}{ Keterangan } \\
\hline Terpotong & $\begin{array}{l}\text { Manusia } \\
\text { (Man })\end{array}$ & $\begin{array}{l}\text { Karyawan kurang hati-hati dalam } \\
\text { melakukan penyetingan pada } \\
\text { mesin. }\end{array}$
\end{tabular}

Mesin Usia mesin yang sudah tua (usang) (Machine) sehingga mesin pengepakan sering tersendat atau mengalami selip (error).

Mesin Penataan tata letak peralatan yang (Machine) kurang mendapatkan perhatian atau kurang rapi.

\begin{tabular}{lll}
\hline Kempes & $\begin{array}{l}\text { Manusia } \\
(\text { Man })\end{array}$ & $\begin{array}{l}\text { Karyawan kurang hati-hati dalam } \\
\text { melakukan penyetingan pada } \\
\text { mesin. }\end{array}$
\end{tabular}

Manusia Karyawan kurang fokus atau teliti (Man) dalam penentuan takaran air dan es pada saat mixing.

Mesin Usia mesin yang sudah tua (usang) (iMachine) sehingga mesin pengepakan sering tersendat atau mengalami selip (error).

Mesin Penataan tata letak peralatan yang (Machine) kurang mendapatkan perhatian atau kurang rapi.

Metode Penataan roti pada box roti setelah (Method) proses pengepakan dan penyusunan box roti yang terlalu terburu-buru dan kurang rapi 


\begin{tabular}{|c|c|c|}
\hline & & $\begin{array}{l}\text { sehingga mengakibatkan roti } \\
\text { terhimpit pada box roti }\end{array}$ \\
\hline & $\begin{array}{l}\text { Metode } \\
\text { (Method) }\end{array}$ & $\begin{array}{l}\text { Waktu pendinginan roti yang } \\
\text { kurang lama. }\end{array}$ \\
\hline \multirow[t]{2}{*}{ Penyok } & $\begin{array}{l}\text { Manusia } \\
\text { (Man) }\end{array}$ & $\begin{array}{l}\text { Karyawan kurang hati-hati dalam } \\
\text { mengangkat roti dari loyang } \\
\text { setelah melalui proses } \\
\text { pemanggangan dan memegang } \\
\text { serta meletakkan roti pada saat } \\
\text { akan dipacking. }\end{array}$ \\
\hline & $\begin{array}{l}\text { Metode } \\
(\text { Method })\end{array}$ & $\begin{array}{l}\text { Penataan pada trolly saat proses } \\
\text { pendinginan yang kurang rapi } \\
\text { sehingga mengakibatkan roti dapat } \\
\text { terhimpit satu sama lain atau } \\
\text { terhimpit dengan trolly. }\end{array}$ \\
\hline \multirow[t]{3}{*}{ Kotor } & $\begin{array}{l}\text { Manusia } \\
\text { (Man) }\end{array}$ & $\begin{array}{l}\text { Karyawan kurang hati-hati ketika } \\
\text { mengangkat trolly dari oven rotary } \\
\text { dan loyang dari oven dack. }\end{array}$ \\
\hline & $\begin{array}{l}\text { Manusia } \\
\text { (Man) }\end{array}$ & $\begin{array}{l}\text { Karyawan kurang memperhatikan } \\
\text { kebersihan dari mesin dan } \\
\text { peralatan yang digunakan }\end{array}$ \\
\hline & $\begin{array}{l}\text { Mesin } \\
\text { (Machine) }\end{array}$ & $\begin{array}{l}\text { Penataan tata letak peralatan yang } \\
\text { kurang mendapatkan perhatian } \\
\text { atau kurang rapi. }\end{array}$ \\
\hline \multirow[t]{3}{*}{$\begin{array}{l}\text { Isi keluar } \\
\text { (bocor) }\end{array}$} & $\begin{array}{l}\text { Manusia } \\
(\text { Man })\end{array}$ & $\begin{array}{l}\text { Karyawan terlalu cepat dalam } \\
\text { pengisian adonan roti dan } \\
\text { kemudian menutup adonan } \\
\text { kembali sehingga posisi adonan } \\
\text { menjadi kurang tepat. }\end{array}$ \\
\hline & $\begin{array}{l}\text { Mesin } \\
\text { (Machine) }\end{array}$ & $\begin{array}{l}\text { Penataan tata letak peralatan } \\
\text { kurang mendapatkan perhatian } \\
\text { atau kurang rapi. }\end{array}$ \\
\hline & $\begin{array}{l}\text { Metode } \\
\text { (Method) }\end{array}$ & $\begin{array}{l}\text { Waktu resting adonan yang kurang } \\
\text { atau terlalu lama. }\end{array}$ \\
\hline
\end{tabular}

Sumber: Data primer diolah, 2017

\section{Membuat Rekomendasi/ Usulan Perbaikan Kualitas dengan Metode Failure Mode and Effect Analysis (FMEA)}

Metode Failure Mode and Effect Analysis (FMEA) adalah metode pengendalian kualitas yang dapat memberikan informasi mengenai prioritas perbaikan yang perlu dilakukan guna mencegah dan mengurangi timbulnya kerusakan produk pada kegiatan produksi berikutnya. Adapun hasil dari metode Failure Mode and Effect Analysis (FMEA) dapat dilihat dalam bentuk tabel analisis yang diringkas seperti terlihat pada tabel berikut:

\begin{tabular}{llllll}
\hline \multicolumn{1}{c}{$\begin{array}{c}\text { Fungsi } \\
\text { Produksi }\end{array}$} & $\begin{array}{c}\text { Mode } \\
\text { Kegagalan }\end{array}$ & S & O & D & RPN \\
\hline $\begin{array}{l}\text { Proses } \\
\text { pengepakan }\end{array}$ & Terpotong & 10 & 9 & 4 & 360 \\
& & 10 & 10 & 4 & 400
\end{tabular}

\begin{tabular}{|c|c|c|c|c|c|}
\hline & & 10 & 4 & 4 & 140 \\
\hline \multirow{6}{*}{$\begin{array}{l}\text { Proses } \\
\text { pengepakan }\end{array}$} & Kempes & 8 & 9 & 4 & 288 \\
\hline & & 8 & 5 & 4 & 160 \\
\hline & & 8 & 10 & 4 & 320 \\
\hline & & 8 & 7 & 3 & 168 \\
\hline & & 8 & 8 & 2 & 128 \\
\hline & & 8 & 4 & 4 & 128 \\
\hline \multirow[t]{2}{*}{ Proses produksi } & Penyok & 7 & 8 & 4 & 224 \\
\hline & & 7 & 7 & 3 & 147 \\
\hline \multirow[t]{3}{*}{ Proses produksi } & Kotor & 7 & 9 & 4 & 252 \\
\hline & & 7 & 9 & 3 & 189 \\
\hline & & 7 & 5 & 4 & 140 \\
\hline \multirow[t]{2}{*}{ Proses produksi } & $\begin{array}{l}\text { Isi keluar } \\
\text { (bocor) }\end{array}$ & 8 & 9 & 3 & 216 \\
\hline & & 8 & 7 & 3 & 168 \\
\hline
\end{tabular}

Sumber; Data primer diolah, 2017

\section{Pembahasan}

Hasil penelitian yang dilakukan peneliti selama 30 hari mulai tanggal 18 Maret s/d 16 April 2017 menghasilkan data primer yaitu data hasil produksi roti manis dan jumlah roti manis yang mengalami kerusakan. Dalam penelitian ini, peneliti menggunakan metode purposive sampling untuk penentuan sampel yang diambil karena keterbatasan peneliti yang tidak dapat mengecek satu per satu produk yang dihasilkan. Sampel yang diambil untuk masing-masing varian roti manis sebanyak 150 pcs. Varian roti manis yang diteliti terdiri dari 6 varian yaitu roti manis kasur, roti manis kasur kombinasi, roti manis kasur cokelat susu, roti manis kasur cokelat, roti manis kasur choco banana, dan roti manis sobek keju, hal ini atas pertimbangan bahwa varian roti yang diteliti adalah varian yang selama periode penelitian selalu diproduksi sehingga total keseluruhan sampel yang diambil adalah 6 varian x 150 pcs $=900$ $\mathrm{pcs} /$ hari.

Berdasarkan hasil obesrvasi yang dilakukan oleh peneliti diketahui bahwa terdapat 7 jenis kerusakan yang terjadi pada PT Indoroti Prima Cemerlang Jember yaitu penyok, kotor, kempes, isi keluar (bocor), terpotong, gosong, dan kurang matang. Akan tetapi, jenis kerusakan yang masuk dalam analisis peneliti hanya 5 jenis, yaitu penyok, kotor, kempes, isi keluar (bocor), dan terpotong. Hal ini dikarenakan untuk jenis kerusakan gosong dan kurang matang tidak pernah terjadi selama periode penelitian. Dari kelima jenis kerusakan tersebut, peneliti menggolongkannya ke dalam dua proses fungsi, dimana penyok, kotor, dan isi keluar (bocor) masuk dalam proses fungsi yaitu proses produksi sedangkan kempes dan terpotong masuk dalam proses fungsi yaitu proses pengepakan. Penggolongan 
tersebut diperkuat oleh pendapat dari Suyadi (2017:74) bahwa tahap pengendalian kualitas meliputi pemeriksaan dan pengawasan kualitas bahan mentah, pemeriksaan atas produk sebagai hasil proses pembuatan, pemeriksaan cara pengepakan dan pengiriman barang ke konsumen, dan mesin, tenaga kerja, dan fasilitas lain yang dipakai dalam proses produksi. Oleh karena itu peneliti membagi kegiatan produksi yang dilakukan oleh perusahaan ke dalam tiga fungsi proses yaitu proses produksi, proses pengepakan, dan proses pendistribusian. Akan tetapi yang akan dianalisis dalam penelitian ini adalah proses produksi dan pengepakan karena penyebab kerusakan pada kedua fungsi proses tersebut lebih kompleks, selain itu apabila ada kerusakan yang terjadi selama proses pendirtribusian maka sudah tidak termasuk dalam pantauan peneliti.

Setelah melakukan teknik pengambilan sampel yaitu tenik purposive sampling maka data yang telah disampling kemudian dimasukkan ke dalam tabel check sheet. Dengan tabel check sheet tersebut diperoleh informasi bahwa total jumlah produksi roti manis PT Indoroti Prima Cemerlang Jember selama 30 hari adalah sebayak 27.000 pcs dan jenis kerusakan roti manis adalah penyok dengan jumlah 89 pcs, kotor dengan jumlah 40 pcs, isi keluar (bocor) dengan jumlah 36 pcs, kempes dengan jumlah 143 pcs, dan terpotong dengan jumlah 334 pcs sehingga total kerusakan roti manis adalah sebanyak 642 pcs. Dari hasil tersebut, peneliti dapat mengetahui bahwa jumlah kerusakan tertinggi (dominan) terjadi pada jenis kerusakan terpotong dengan jumlah kerusakan sebanyak 334 pcs dengan presentase kerusakan sebesar 52,02\% dari jumlah kerusakan keseluruhan, kemudian disusul jenis kerusakan kempes dengan jumlah kerusakan sebanyak 143 pcs dengan presentase kerusakan sebesar $22,27 \%$, selanjutnya penyok dengan jumlah kerusakan sebanyak 89 pcs dengan presentase kerusakan sebesar 13,86\%, kemudian kotor dengan jumlah kerusakan sebanyak 40 pcs dengan presentase kerusakan sebesar $6,23 \%$, dan terendah yaitu isi keluar (bocor) dengan jumlah kerusakan sebanyak 36 pcs dengan presentase kerusakan sebanyak 5,61\%.

Adapun hasil pengendalian kualitas produk secara statistik dengan menggunakan peta kendali $\mathrm{p}$ ( $p$ chart) menunjukkan bahwa kerusakan produk yang terjadi selama periode penelitian masih berada dalam batas kendali, hal ini terbukti dengan semua titik berada di dalam garis UCL dan LCL. Adapun UCL adalah sebesar 0,0085, LCL sebesar 0,0390, dan $p$ sebesar 0,0238. Meskipun demikian, pihak perusahaan tetap memerlukan pengendalian kualitas secara berkelanjutan sebagai upaya untuk mengurangi terjadinya kerusakan produk yang selama ini selalu terjadi.

Untuk dapat melakukan pengendalian kualitas tersebut maka penting sekali bagi PT Indoroti Prima Cemerlang Jember untuk mengetahui faktor-faktor yang menyebabkan terjadinya kerusakan produk. Adapun faktor-faktor penyebab terjadinya kerusakan roti manis pada perusahaan tersebut dapat disebabkan oleh tiga faktor yaitu manusia (man), mesin (machine), dan metode (method). Adapun faktor penyebab terjadinya kerusakan produk untuk setiap perusahaan pasti berbeda karena dipengaruhi oleh keadaan perusahaan yang bersangkutan seperti halnya hasil penelitian dari Adhi Muhammad Aulia Rahman (Tanpa
Tahun) yang juga meneliti tentang roti yaitu roti tawar. Hasil penelitian menunjukkan bahwa faktor penyebab kerusakan roti tawar adalah manusia (man), metode (method), dan bahan baku (material), dan mesin (machine).

Setelah diketahui faktor penyebab kemudian peneliti melakukan analisis selanjutnya yaitu dengan menentukan penyebab kerusakan untuk setiap masing-masing jenis kerusakan berdasarkan faktor-faktor penyebab kerusakan tersebut dan kemudian dapat dicari solusi/usulan perbaikan yang dapat diberikan untuk mengurangi terjadinya kerusakan produk pada periode berikutnya. Untuk mengoptimalkan pengendalian kualitas yang dilakukan maka perusahaan harus mengetahui prioritas perbaikan yang harus lakukan untuk mengatasi kerusakan produk tersebut.

Prioritas perbaikan dapat diketahui dengan melihat hasil pada metode Failure Mode and Effect Analysis (FMEA). Jenis kerusakan yang terjadi pada proses pengepakan secara umum disebabkan oleh faktor mesin (machine) (RPN 400, 320,128 ) sehingga prioritas perbaikan yang harus dilakukan terlebih dahulu adalah dengan melakukan perawatan (maintenance) secara rutin pada mesin pengepakan, hal ini karena mesin pengepakan tersebut sudah tua sehingga perlu banyak mendapatkan perhatian, supervisor harus memantau dan menghimbau kepada seluruh karyawan terkait dengan kebersihan dan penataan mesin dan peralatan yang digunakan, peningkatan koordinasi antar karyawan bagian pengepakan (packing) dan teknisi untuk melakukan pengawasan secara rutin pada mesin pengepakan agar suhu pada mesin tetap stabil. Nilai RPN tertinggi kedua yaitu faktor manusia (man) (RPN 360, 288, 160) dengan perbaikan yang seharusnya dilakukan adalah supervisor harus melakukan pengawasan yang lebih ketat dan rutin serta memberikan teguran kepada karyawan agar tidak kembali melakukan kesalahan dan meningkatkan koordinasi antar karyawan yang bekerja dalam satu mesin. Nilai RPN tertinggi ketiga adalah faktor metode (method) (RPN 168, 128) dengan perbaikan yang seharusnya dilakukan adalah membuat pedoman metode kerja secara tertulis dan melakukan briefing serta evaluasi kepada karyawan secara rutin untuk mengurangi terjadinya kesalahan yang disebabkan keteledoran karyawan yang bersangkutan dan supervisor harus memantau dan menghimbau karyawan untuk selalu meningkatkan koordinasi antar karaywan bagian packing dan picking.

Sedangkan jenis kerusakan pada proses produksi secara umum disebabkan karena faktor manusia (man) (RPN 252, $224,216,189)$ dengan prioritas perbaikan yang harus dilakukan terlebih dahulu adalah supervisor harus melakukan pengawasan yang lebih ketat dan rutin serta memberikan teguran kepada karyawan agar tidak kembali melakukan kesalahan, selain itu supervisor juga harus menghimbau karyawan untuk lebih memperhatikan kebersihan mesin dan peralatan secara rutin setelah selesai digunakan. Nilai RPN tertinggi kedua adalah faktor mesin (machine) (RPN 140) dengan perbaikan yang seharusnya dilakukan adalah supervisor harus menghimbau kepada seluruh karyawan untuk lebih memperhatikan penataan peralatan produksi pada saat digunakan atau tidak agar selalu menatanya dengan rapi. Nilai RPN tertinggi ketiga adalah faktor metode (method) (RPN 168, 147) dengan 
perbaikan yang seharusnya dilakukan perusahaan adalah supervisor harus memantau dan menghimbau kepada karyawan untuk meningkatkan koordinasi antar setiap bagian dan membuat pedoman metode kerja secara tertulis dan melakukan briefing serta evaluasi kepada karyawan rutin untuk mengurangi terjadinya kesalahan yang disebabkan keteledoran karyawan yang bersangkutan.

\section{Simpulan}

Berdasarkan hasil penelitian ini dapat disimpulkan bahwa: 1) Jumlah produksi roti manis selama 30 hari yaitu mulai tanggal 18 Maret s/d 16 April 2017 pada PT Indoroti Prima Cemerlang Jember adalah sebanyak 27.000 pcs dengan jumlah kerusakan yang terjadi adalah sebanyak 642 pcs. Terdapat lima jenis kerusakan produk yang terjadi selama periode penelitian tersebut yaitu penyok dengan jumlah 336 pcs, kotor dengan jumlah 143 pcs, isi keluar (bocor) dengan jumlah 89 pcs, kempes dengan jumlah 40 pcs, dan terpotong dengan jumlah 36 pcs. Berdasarkan hasil analisis menggunakan alat bantu statistik dengan peta kendali $\mathrm{p}(p$ chart) menunjukkan bahwa kerusakan produk yang terjadi masih berada di dalam batas kendali, hal ini dapat dibuktikan bahwa semua titik berada di dalam garis batas Upper Control Limit (UCL) dan Limit Control Limit (LCL). Keadaan tersebut menunjukkan bahwa pengendalian kualitas untuk produk roti manis dapat dikatakan baik; 2) Berdasarkan diagram pareto, diketahui jenis kerusakan dengan jumlah tertinggi (dominan) hingga terendah yang terjadi dalam kegiatan produksi PT Indoroti Prima Cemerlang Jember yaitu terpotong dengan presentase $52,02 \%$, kempes dengan presentase $22,27 \%$, penyok dengan presentase $13,86 \%$, kotor dengan presentase $6,23 \%$, dan isi keluar (bocor) dengan presentase 5,61\%. Berdasarkan hasil analisis menggunakan diagram sebab akibat (fishbone diagram) dapat diketahui bahwa penyebab kerusakan produk roti manis disebabkan oleh beberapa faktor yaitu manusia (man), mesin (machine), dan metode (method); 3) Berdasarkan hasil analisis menggunakan metode Failure Mode and Effect Analysis (FMEA) dapat diketahui bahwa kerusakan produk yang terjadi pada proses produksi secara umum disebabkan oleh faktor manusia (man) dengan prioritas perbaikan yang harus dilakukan adalah karyawan bagian pengepakan harus melakukan setting ulang mesin dan teknisi harus memberikan perawatan (maintenance) secara rutin pada mesin pengepakan setiap harinya, sedangkan kerusakan produk pada proses pengepakan secara umum disebabkan oleh faktor mesin (machine) sehingga prioritas perbaikan yang harus dilakukan adalah supervisor harus melakukan pengawasan yang lebih ketat dan rutin serta memberikan teguran kepada karyawan agar tidak kembali melakukan kesalahan.

\section{Ucapan Terimakasih}

Penulis mengucapkan banyak terimakasih kepada PT Indoroti Prima Cemerlang Jember yang telah memperkenankan dan mempermudah penulis untuk melakukan penelitian di bagian produksi sehingga penelitian ini dapat diselesaikan dengan baik.

\section{Referensi}

Adhi Muhammad Aulia Rahman. (Tanpa Tahun). Analisis Pengendalian Kualitas Produk Roti Rawar Mr. Bread dengan Metode FMEA (Di bagian Produksi CV.Essen). Jurnal Ilmiah. Universitas Diponegoro. .

Hansen dan Mowen. 2001. Manajemen Biaya. (Diterjemahkan oleh Benyamin Molan). Buku II. Jakarta: Penerbit Salemba Empat.

Heizer. Jay dan Barry Render. 2006. Manajemen Opreasi (Operations Manajemen). Jakarta: Salemba Empat.

Kosasih, Wilson., Adianto, dan Erickson. 2015. Analisis Pengendalian Kualitas Produk Bucket Tipe ZX 200 GP dengan Metode Statistical Process Control dan Failure Mode and Effect Analysis (Studi Kasus: PT. CDE). Jurnal Ilmiah. Universitas Tarumanegara. Vol. 3 No. 2, 1-9.

Sakti. Bima Segara. 2014. Analisis Pengendalian Kualitas Cerutu dengan Menggunakan Statistical Process Control (SPC) pada PT Mangli Djaya Rava.. Skripsi. Fakultas Ekonomi Universitas Jember.

Suvadi Prawirosentono. 2007. Filosofi Baru Tentang Manajemen Mutu Terpadu Abad 21 "Kiat Membangun Bisnis Kompetitif”. Edisi dua. Jakarta: Bumi Aksara. 